THE EUROPEAN JOURNAL OF LIFE WRITING VOLUME VIII(2019)R43-R47

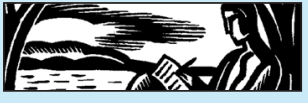

Jon Savage, This Searing Light, The Sun and Everything Else: Joy Division The Oral History (London: Faber and Faber, 2019, ISBN 9780571345373).

Stephen Morris, Record Play Pause: Confessions of a Post-Punk Percussionist. Volume 1 (London: Constable, 2019, ISBN 9781472126191).

\title{
Dennis Kersten
}

Radboud University, Nijmegen, the Netherlands

The book included in the "Definitive Edition" of the 2019 remaster of New Order's debut album Movement (1981) is illustrated with photographs of the band's original instruments. The first, a picture of Ian Curtis' microphone stand, is a harrowing reminder of the circumstances under which the album was conceived. It contained the first new music by a band formerly known as Joy Division, a name they chose to abandon after their front man had committed suicide in May, 1980. Electric guitars, keyboards and drums may be beautiful objects to behold in their own right, but a microphone stand without a singer is a forlorn sight. As suggested by that first picture in the Movement book, New Order came from the void left by Curtis's absence, one that simultaneously began to cast a dark shadow over their earlier history as Joy Division.

Coincidentally, on the exact same day in April 2019 that Movement was re-released, Jon Savage published his highly anticipated oral history of Joy Division, This Searing Light, The Sun and Everything Else. Based on recent interviews, it documents the short, but incredibly productive period in which Joy Division recorded an oeuvre that would prove immeasurably influential. A month after Savage, drummer Stephen Morris presented the first volume of his autobiography, Record Play Pause: Confessions of a Post-Punk Percussionist, following in the footsteps of band mates Peter Hook (Unknown Pleasures, 2012, and Substance, 2016) and Bernard Sumner (Chapter and Verse, 2014). Clearly, Joy Division retrospection is at a high at the moment, and not just in life writing. Savage was also involved in the True Faith exhibition about Joy Division and New Order at Manchester Art Gallery in 2017. Next to that, he has co-edited a book with facsimiles of Curtis' handwritten lyrics (So This is Permanence, from 2014). 
Joy Division have become the subject of academic scrutiny as well, as evidenced by Heart EO Soul: Critical Essays on Joy Division (2018), edited by Martin J. Power, Eoin Devereux and Aileen Dillane. The new books by Savage and Morris do not simply rehash what has already been said about Ian Curtis and Joy Division: the first has an intriguing form (it calls itself an oral history), while the second adds personal insights in chapters that approach the novelistic.

Oral histories like Savage's are gaining popularity within rock life writing, possibly because the form lends itself particularly well to the telling of the histories of collectives like bands. In 2017, Daniel Rachel won the Penderyn Music Book Prize for Walls Come Tumbling Down, a much needed detailed account of Rock Against Racism, 2 Tone and Red Wedge, citing an impressive number of key players without the interference of a narrator's "voice-over". Lizzy Goodman's Meet Me in the Bathroom (2017) applies the same format to the story of the "rebirth" of guitar rock in turn-of-themillennium New York City, while Dylan Jones's David Bowie: A Life (2017) experiments with oral history in a book about only one individual. The results vary: in Rachel's long book, readers might forget who they are reading about or listening to, but this somehow seems exactly right in a book about community spirit or the power of the "union". There are no dominant voices or stars: in fact, the oral history form works as a great leveller in Walls Come Tumbling Down. Goodman's less successful book is more of a portrait of a place in a particular time than a story of a group of people with a shared purpose; it tries too hard to make The Strokes, Interpol and LCD Soundsystem look like a generation, while these artists are especially united by their emergence around $9 / 11$ and the arrival of the Internet as a music publishing platform. David Bowie: A Life may not be about a collective at all, but, of course, chameleonic Bowie does make the perfect subject for a book built on the premise that one person may mean 1,000 things to 1,000 people, instead of one thing to one biographer. As Jones shows, amongst other things by using oral history to great effect, "David Bowie" is first and foremost an idea, and one that exists in the memories, brought together in his book, of the people who listened to, wrote about and worked with the singer.

Oral history in book form has its disadvantages as well. Apart from the fact that readers do not actually get to hear the voices of the "dramatis personae" (with indications of their geographical backgrounds and their ages), these histories are more constructed than the absence of a narrator's commentary implies. Rachel, Goodman and Jones present chronological collages of seemingly unedited transcriptions of interviews, but the order in which they are placed does betray the biographers' guiding hands. In Jones's book, photographer David Bailey is quite critical 
of Bowie, but his words, presumably from the same interview, are spread across two pages (132-3 and 292-3), which dampens their impact. Also, the interviewees' perspectives on Angie Bowie diverge wildly, but because opposing opinions are not discussed in one place, it may be hard for readers to draw their own conclusions about her contributions to Bowie's work.

The shape of Jon Savage's This Searing Light and how it divides weight across the topics it covers is no less significant. It starts with a chapter on Manchester, Salford and Macclesfield (the hometowns of the members of Joy Division as well as the "psychogeographical" home of the band's sound) and spends most time on Spring, 1980, ending with a separate chapter on Ian Curtis's death. Moreover, though not as a result of Savage's composition of his material, Curtis himself is largely silent in the oral history of a band whose legacy has long been overshadowed by his mythologizing. The lack of archival recordings of Curtis means he is only represented by five quotes (poignantly, the last time he can be "heard" is in an excerpt from a transcript of a hypnosis session with Bernard Sumner), but his absence from Savage's text resonates symbolically with the gap he left behind in the lives of others. Indeed, the more clearly Curtis comes to the fore as the band's director in other people's words, the stronger the sense of loss that permeates the band's story is evoked. As the main guide in their musical education, Curtis taught founding members Sumner and Hook about music and how to make it "maniac" (53). Later, he became their "riff spotter" (96). It was Curtis who, during jam sessions with the band, recognized drum rhythms, bass lines and guitar patterns with song potential.

Inevitably, Curtis and his fate loom large in Stephen Morris' autobiography as well. A number of times, Record Play Pause hints at the difficulty of writing your life when parts of it have been mediatized to such an extent that you may lose touch with your own memories and mistake myth for reality. In that sense, the book ends on a doubly sad note, with Morris losing Curtis a second time: "As time went on, I began to feel less and less sure that I had actually known him at all" (377). Understandably, the passages in which Morris reflects on this issue are the only ones in his generously humorous book informed by anger: "Within a week of his death the fables started... He was a singer - they got that right (not a genius or poet yet) - and he was dead-also correct. As for the rest, you can't libel the dead, so go to town" (371). His novelistic version of the story of Curtis's suicide and the moment he learned about his passing is shockingly emotional, precisely because it succeeds at avoiding cliché. Volume I of Morris' “confessions” does not predictably end with Curtis' death either. Its final chapter relates how Sumner, Hook and Morris travel to New York as New Order and, later, start preparing for the recording 
of Movement. Record Play Pause is a welcome addition to the Joy Division historiography, especially for the portrait it paints of Morris' adolescence and the world in which punk arrived-or detonated, rather.

The overall picture that emerges both from Savage's oral history and Morris' autobiography is of a group of people who literally played everything by ear. Especially Sumner emphasizes how the band never talked about or questioned their own music (Savage 217), Curtis's iconic, but unsettling performances (123), or his epilepsy and its consequences. As they say so themselves, they were too young, male and Northern to discuss personal emotions or the nature of what they were doing musically. In Record Play Pause, Morris confirms that Joy Division had "a communication problem" (174), the source, he writes, of the current acrimony between Hook and Sumner. The band's environment did not always encourage responsible behaviour either-specifically in relation to Curtis' depressions and increasingly severe epileptic fits. Gigs and tours that should have been cancelled went ahead despite their risk to Curtis' condition. As Hook states: "There were no adults" (Savage 244).

There certainly were candidates for the role of grown-up in the Joy Division entourage, most of whom are quoted in Savage's book as well. Label owner Tony Wilson and manager Rob Gretton should perhaps have protected Curtis and the other three more, but Savage justifiably puts the spotlight on the management team and other loyal, early supporters of the band. Joy Division always were a combination of extraordinary talent, in and outside the band. No freedom to musically experiment without Wilson's non-commercial work ethic, no iconic album cover art without designer Peter Saville and, above all, no unique and instantly recognizable post-punk sound without Martin Hannett, the producer. With a quote from Wilson in its main title, Savage's oral history grants "Mr. Manchester" a final word. It is a fitting tribute to a man who would continue to support New Order until his death in 2007. Touchingly, there was a portrait of Wilson high above the exit of the True Faith exhibition at Manchester Art Gallery: he was the man who oversaw it all, without ever standing in the way of the artists whose potential he helped realize.

The fact that Curtis is hardly heard in the oral history, combined with the lack of input from Gretton, adds to the suggestion that Joy Division were speeding on the motorway with no-one behind the steering wheel. Readers will know at any turn what their story's destiny is, but while reading about the weeks leading up to Curtis's death, it does, indeed, feel like the momentum fueled by the band's mutually reinforcing passion and ambition is fast taking them to the point of no return. Morris leaves his readers with a memorable image for the post-Curtis Joy Division: "I think 
of Joy Division as some sort of deep space rocket that escaped our gravitational pull with Ian's suicide" (374).

Neither Savage's oral history nor Morris' autobiography will bring back the rocket and reverse the mythologizing of Joy Division that forever threatens to alienate the people who were actually in that band. With at least four rock memoirs between them, its surviving members do appear more ready to talk about themselves and their music than they have ever been. If only they solved their almost existential communication problem and talked to each other more as well-at least, Hook and Sumner. The oral history of This Searing Light comes close to a group autobiography, however; its very form makes them come across as the tight unit they were on stage and in the studio forty years ago.

\section{WORKS CITED}

Goodman, Lizzy. Meet Me in the Bathroom. Rebirth and Rock and Roll in New York City 2001-2011. New York City: Dey Street Books, 2017.

Jones, Dylan. David Bowie: A Life. London: Preface, 2017.

Morris, Stephen. Record Play Pause: Confessions of a Post-Punk Percussionist. Volume 1. London: Constable, 2019.

Rachel, Daniel. Walls Come Tumbling Down: The Music and Politics of Rock Against Racism, 2 Tone and Red Wedge. London: Picador, 2016.

Savage, Jon. This Searing Light, The Sun and Everything Else: Joy Division The Oral History. London: Faber and Faber, 2019. 